\title{
Factors Affecting Treatment Compliance In Tb Patients (Tuberculosis) During Pandemic Covid-19 At Labuang Baji Makassar Hospital
}

\author{
Imelda Appulembang ${ }^{1 *}$, Ana LitaLutoWujon ${ }^{2}$, Dana Briggs ${ }^{3}$, Maher Nasser Abdullah $^{4}$ \\ ${ }^{1}$ Lecturer OfBechalor Health Nursing, STIKES Gunung Sari, Indonesia \\ ${ }^{2}$ Health Nursing, STIKES Gunung Sari, Indonesia \\ ${ }^{3}$ California State University, Monterey Baydisabled, Marina, United States \\ ${ }^{4}$ Al-Muthanna University, Iraq \\ ${ }^{*}$ Corresponding author: \\ Email : imeldaappulembang@gmail.com
}

\begin{abstract}
.
Tuberculosis (TB) is an infectious disease caused by the bacteria Mycobacterium tuberculosis (World Health Organization. Tuberculosis (TB) is also one of the main public health problems that has become one of the biggest threats in the world, in addition to the COVID-19 pandemic. Currently, TB (tuberculosis) is one of the risk factors for a person to be susceptible to being infected with COVID-19. The aim of the study was to determine the factors that influence medication adherence in TB (tuberculosis) patients during the Covid19 pandemic at the LabuangBaji Hospital, Makassar. The research design used in this study is descriptive analytic research using a cross sectional study design. To determine the relationship between the independent variable and the dependent variable using joint measurements, the population is 128 people. respondents, the measuring instrument for measuring data is using a questionnaire. There is an influence between the knowledge variable about TB disease (tuberculosis) on the adherence to treatment of TB patients (tuberculosis) during the covid-19 pandemic at LabuangBaji Hospital Makassar showing a value $(0.005<0.05)$, There is an influence between the variables of family support on treatment adherence TB patients (tuberculosis) during the covid-19 pandemic at LabuangBaji Hospital Makassar showed a value $(0.003<$ $0.05)$. There was an influence between the anxiety variable on adherence to treatment for TB patients (tuberculosis) during the covid-19 pandemic, LabuangBaji Hospital Makassar showed a value $(0.001<0.05)$. There is an influence between knowledge of TB disease (tuberculosis), family support, anxiety and adherence to treatment for $T B$ patients during the covid-19 pandemic at LabuangBaji Hospital Makassar
\end{abstract}

Keywords: Knowledge, anxiety family support, medication adherence

\section{INTRODUCTION}

Tuberculosis (TB) is an important public health problem in the world, tuberculosis (TB) occurs in every part of the world. In 2019, the largest number of new TB cases occurred in Southeast Asia, with 44\% of new cases, followed by Africa, with $25 \%$ of new cases and the Western Pacific with $18 \%$. In 2019 there were as many as $87 \%$ of new TB cases occurring in 30 countries with a high burden of TB (tuberculosis). Eight countries that accounted for two thirds of pulmonary TB cases were in India, Indonesia, China, Philippines, Pakistan, Nigeria, Bangladesh and South Africa. That is, 1.4 million people died of TB (tuberculosis) in 2019 (including 208,000 people with HIV). Worldwide, TB (tuberculosis) is one of the top 10 causes of death and a leading cause of single infectious agent. In 2019, it is estimated that around 10 million people have TB (tuberculosis) worldwide. 5.6 million men, 3,2 million women and 1.2 million children. TB (tuberculosis) is present in all countries and age groups. But TB (tuberculosis) can be cured and prevented (WHO, 2020).Tuberculosis (TB) is an infectious disease caused by the bacteria Mycobacterium tuberculosis (World Health Organization. Tuberculosis (TB) is also one of the main public health problems that has become one of the biggest threats in the world. In addition, during the COVID-19 pandemic, TB (tuberculosis) can be one of the risk factors for a person to be susceptible to being infected with covid-19 and cause higher mortality than patients who only suffer from pulmonary TB disease or covid-19.

There are an estimated 845,000 new TB (tuberculosis) cases in Indonesia, while in 2018, the proportion of TB (tuberculosis) cases in Indonesia was 842,000 cases (Infodatin TBC Indonesia, 2020). The 
prevalence of pulmonary TB in South Sulawesi experienced an increase in cases in 2007 and 2013 with a percentage of $0.3 \%$. Although it is still below the national percentage $(0.4 \%)$, it is still considered necessary to deal with the addition of cases every year. This can be shown by the number of patients with smear positive pulmonary TB in South Sulawesi in 2014 was still high, namely 8,859 cases. Based on all regencies/cities in South Sulawesi, Makassar City was ranked first with the number of positive smear pulmonary TB patients as many as 1,866 cases, followed by Gowa Regency with 722 cases and Bone Regency with 587 cases (South Sulawesi Provincial Health Office, 2014).Based on what has been obtained from the Indonesian Public Health Student Scientific Periodic (BIMKMI) in 2009 the achievement rate in drug administration was $91 \%$ but the number of new case findings was around $71 \%$, so in 2012 the treatment achievement rate decreased to $87 \%$ with new case findings. namely $40.47 \%$ (Ministry of Health 2016).

Tuberculosis (TB) is a burden of health problems in Indonesia to date. At the same time, Indonesia is also facing a coronavirus (Covid-19) outbreak and TB patients must be more vigilant. Both of these diseases are respiratory pandemics that are transmitted through droplets (splash), affecting a wide age range such as the elderly and people with special health conditions such as those with chronic lung disorders, and children. Some of the symptoms of TB such as cough, fever, and feeling weak are also experienced by COVID-19 patients, thus making us aware of how vulnerable they are if TB patients do not seek treatment, because their immune system and lung conditions are also more susceptible to infection (Kemenkes, 2020).Family support in this case is to encourage patients to comply with taking their medicine, show sympathy and concern, and not to avoid sufferers from their illness. In providing support for a member who suffers from TB (tuberculosis), support from all family members is very important for the healing and recovery process of patients (Septia\& Sabrina, 2014).Anxiety in TB patients (tuberculosis) is closely related to the feeling of excessive worry about the disease that is being suffered. Patients diagnosed with pulmonary TB (tuberculosis) have feelings of fear in themselves that can be in the form of fear of treatment (Shen et al, 2014).With the occurrence of Covid-19, it has a very impact on TB sufferers, although the system provides concessions for TB sufferers to come to the waiter to continue treatment, but sufferers feel afraid and anxious about contracting Covid so that patients choose not to go to health services to continue treatment (Ricvan Dana Nintendo 2020).

\section{METHODS}

The type of research used is descriptive analytic research using a cross sectional study design. The population in this study were all TB patients who were treated in the care room of RSUD LabuangBaji Makassar with the sampling technique in this study with 33 samples of purposive sampling. Questionnaires are a number of written questions that are used to obtain information from respondents in the sense of reports about their personalities, or things that are known to them, which consist of 10 questions.

\section{RESULT AND DISCUSSION}

The results of this study indicate that from the results of the study consisting of 33 respondents, there were $14(42.4 \%)$ male respondents, and 19 (57.6\%) female respondents. the highest number of education frequencies is in the last education category SD and SMA which have 10 people $30.3 \%$ the lowest number of education frequencies is in the last education category S1 which has 4 people $12.1 \%$. those who have the highest age frequency are at the age of $41-50$ with a total frequency of 13 people $39.4 \%$ and those who have the lowest age frequency are at the age of 51-60 with a total frequency of 4 people 12.15

Distribution of Respondents by Level of Knowledge of Covid-19 in the Inpatient Room of LabuangBaji Hospital Makassar

\begin{tabular}{lccc}
\hline $\begin{array}{c}\text { Covid } 19 \text { knowledge } \\
\text { level }\end{array}$ & Frequency (n) & Percentage \% \\
\hline Decent & 16 & $48,5 \%$ \\
Deficient & 17 & $51,5 \%$ \\
\hline Amount & $\mathbf{3 3}$ & $\mathbf{1 0 0 \%}$ \\
\hline
\end{tabular}


Distribution of Respondents by Level of Knowledge of TB (tuberculosis) in the Inpatient Room of LabuangBaji Hospital, Makassar

\begin{tabular}{lll}
\hline $\begin{array}{l}\text { Pengetahuanpenyakit } \\
\text { TB (tuberculosis) }\end{array}$ & Frequency (n) & Percentage \% \\
\hline Decent & 19 & $57,6 \%$ \\
Deficient & 14 & $42,4 \%$ \\
\hline Amount & $\mathbf{3 3}$ & $\mathbf{1 0 0 \%}$ \\
\hline
\end{tabular}

Distribution of Respondents by Level of Knowledge of Covid-19 in the Inpatient Room of LabuangBaji Hospital Makassar

\begin{tabular}{|c|c|c|}
\hline Family Support & Frequency (n) & Percentage $\%$ \\
\hline Decent & 16 & $48,5 \%$ \\
\hline Deficient & 17 & $51,5 \%$ \\
\hline Amount & 33 & $100 \%$ \\
\hline
\end{tabular}

Distribution of Respondents by Level of Anxiety in the Inpatient Room at Labuang Baji Hospital Makassar

\begin{tabular}{lccc}
\hline & Fear & Frequency (n) & Percentage \% \\
\hline Slight & 15 & $45,5 \%$ \\
Moderate & 18 & $54,5 \%$ \\
\hline Amount & $\mathbf{3 3}$ & $\mathbf{1 0 0 \%}$ \\
\hline
\end{tabular}

Distribution of Respondents Compliance with Treatment for TB Patients (tuberculosis) in the Inpatient Room at LabuangBaji Hospital Makassar

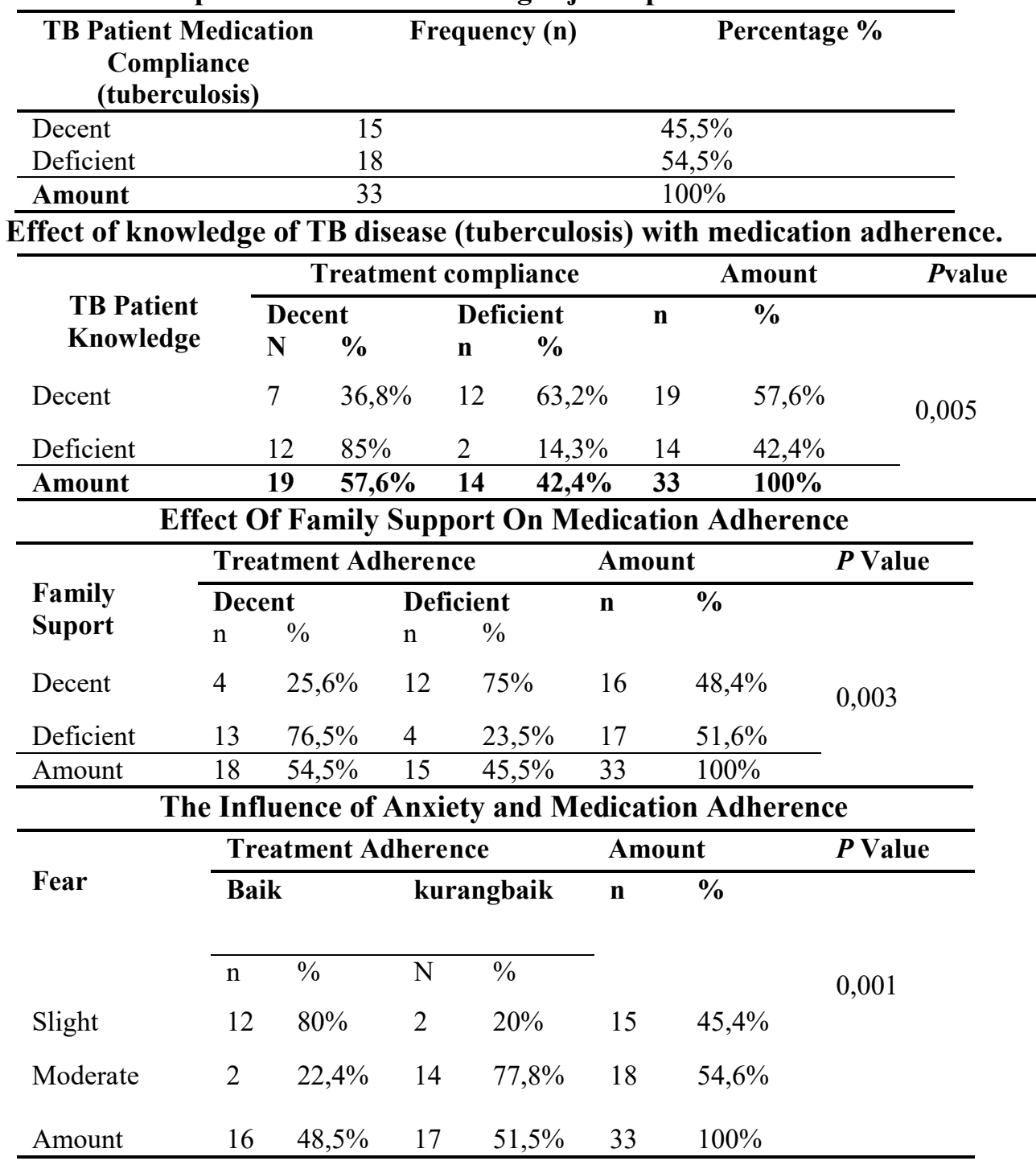




\section{The effect of knowledge of TB disease (tuberculosis) with adherence to treatment of TB patients (tuberculosis) in the COVID-19 pandemic mass at the LabuangBaji Hospital Makassar}

Based on the frequency table of knowledge about TB disease (tuberculosis) it shows that of the 33 respondents who have good knowledge of TB (tuberculosis) 19 people (57.6\%) and who lack knowledge, as many as 14 people (42.4\%) and compliance 15 people (45.5\%) had good treatment and 18 people (54.5\%) did not comply. From the results of the hypothesis test, it showed that patients who had less knowledge about TB (tuberculosis) and less adherence to treatment were $2(14) ., 3 \%$ ) and those who have poor knowledge and good treatment adherence are 12 people (85.\%), patients with good knowledge and poor medication adherence are 12 people (63.2\%) while patients with good knowledge and good medication adherence are 7 people (36.8\%). From the results of the analysis using the Chi-Square Test, it shows that the significant value has a significant effect on medication adherence in TB (tuberculosis) patients during the covid-19 pandemic in the inpatient room of LabuangBaji Hospital Makassar with $p$ value $=(0.005<0.05)$.Knowledge about TB disease (tuberculosis) According to Notoatmodjo in Yuliana (2017), pulmonary TB is one of the most important factors in the transmission of pulmonary TB. Knowledge is closely related to compliance, if a patient knows the importance of adherence to tuberculosis (TB) treatment and knows the risks that will arise if he does not comply with treatment, then the patient's awareness of treatment will increase and the healing process will go well as planned.

(Riskawati, et al. 2018).Compliance is very important in healthy living behavior. Compliance with taking OAT drugs is taking medicines that have been prescribed by a doctor at the right time and at the right dose. Treatment will only be effective if the patient obeys the rules in using the drug (Laban, 2008 in Anita Yeni et al. 2015) This is in line with the research conducted by (Anita Yeni et al. 2015) with the title Tuberculosis Patient Knowledge Has Implications for Medication Compliance. knowledge and adherence to treatment of TB patients (tuberculosis) was found that there were $8(40 \%)$ respondents who had less knowledge, as many as 6 respondents $(30 \%)$ who were classified as non-adherent in TB treatment (tuberculosis) and 2 respondents (10\%) classified as adherence to TB (tuberculosis) treatment. Of the 9 respondents (45\%) who had enough, all of them were classified as obedient in TB treatment. 3 respondents (15\%) who had good knowledge were all classified as obedient in TB treatment. Of the respondents 8 respondents $(40 \%)$ are known to be non-adherent in TB treatmentAccording to the researcher's assumption, knowledge can affect adherence to treatment for TB patients (tuberculosis). TB (tuberculosis) is not good, it will affect the adherence to treatment in TB patients (tuberculosis) so that it can be concluded that knowledge significantly affects the adherence to treatment of a TB patient (tuberculosis).

2. The influence of family support on medication adherence in TB (tuberculosis) patients during the covid-19 pandemic

Based on the support frequency table shows that of the 33 respondents who have good family support as many as 16 people (48.5\%) and poor family support, as many as 17 people (51.5\%) and compliance with good treatment as many as 15 people $(45.5 \%)$ and 18 people $(54.5 \%)$ who were not compliant with treatment. From the results of the hypothesis test, it was found that there were 4 patients with poor family support and poor medication adherence and 4 people $(23.5 \%)$ who had good family support and medication adherence. 13 people (76.5\%), good family support and poor medication adherence were 12 people $(75 \%)$ while patients with good family support and good medication adherence were 4 people (25.6\%). From the results of the analysis using the Chi-Square Test, it shows that the significant value has a significant effect on adherence to treatment in TB (tuberculosis) patients during the COVID-19 pandemic in the inpatient room at LabuangBaji Hospital Makassar with $p$ value $=(0.003<0.05)$.

This is in line with research conducted by (ArniWianti 2017) with the research title Relationship between Family Support and Drug Compliance in Pulmonary Tuberculosis Patients at the Kaladawa Health Center, Tengal Regency. the results obtained (36.8\%) did not comply with taking medication, $45.6 \%$ did not receive family support as much as $54.4 \%$, there was no relationship between family support and medication adherence in Tuberculosis (TBC) patients.Family support is the attitude, action and acceptance of the family 
towards a sick family member. Family members view that supportive people are always ready to provide help and assistance if needed. Family support is one of the factors that influence non-adherence in TB (tuberculosis) treatment. Without family support, this TB (tuberculosis) treatment program is difficult to carry out on schedule. In this case, family support is really needed to motivate family members who suffer from TB (tuberculosis) to continue treatment in accordance with treatment recommendations (Kemenkes RI, 2010 in ArniWianti 2017).According to the researcher's assumption, family support can affect medication adherence in TB patients (tuberculosis). healing and recovery. So it can be concluded that family support has a significant effect on adherence to treatment for TB patients (tuberculosis).

\section{The effect of anxiety on medication adherence in TB (tuberculosis) patients during the COVID-19 pandemic.}

Based on the support frequency table, it shows that from 33 respondents who had severe anxiety as many as 18 people $(54.5 \%)$ and mild anxiety as many as 15 people $(45.5 \%)$ and good treatment adherence as many as 15 people $(45.5 \%)$ and those who did not. 18 people $(54.5 \%)$ were obedient in treatment. From the results of hypothesis testing, there were 14 patients with severe anxiety and less adherence to treatment (77.8\%) and 2 people with severe anxiety and good medication adherence (22.4). \%), mild anxiety and poor medication adherence were 2 people $(20 \%)$ while patients with mild anxiety and good medication adherence were 12 people (80\%). From the results of the analysis using the Chi-Square Test, it shows that the significant value has a significant effect on medication adherence in TB (tuberculosis) patients during the covid-19 pandemic in the inpatient room at LabuangBaji Hospital Makassar with $p$ value $=(0.001<0.05)$.

The increasing level of anxiety is a mental health problem that often occurs during a pandemic, including the ongoing Covid-19 pandemic, World Health Organization (WHO, 2020). This is in line with research conducted by (Eli Kurniasi, VinaJovitiaNurfajriani 2021). With the title Description of Pulmonary TB Anxiety Levels in Literature Review, the results of measuring the anxiety level of pulmonary TB patients before conducting health counseling showed the effect of TB patients' anxiety levels before health counseling was conducted. obtained as many as $32 \%$ of the category of mild anxiety, moderate, severe $4 \%$ of people in the panic category. After health counseling showed a reduction in anxiety levels with mild anxiety results as many as 9 people (36\%), 11 people (44\%) experienced moderate anxiety and 5 people $(20 \%)$ experienced severe anxiety. very influential also with adherence to treatment in patients with TB (tuberculosis)Anxiety can affect adherence to treatment for TB patients (tuberculosis). (tuberculosis) so that it can be concluded that anxiety significantly affects the adherence to treatment of a TB patient (tuberculosis). We can see that during this pandemic, people are afraid to go to the hospital because the signs and symptoms are almost the same as TB (tuberculosis).

\section{CONCLUSION}

1. There is an influence between the variables of knowledge about TB disease (tuberculosis) on adherence to treatment of TB patients (tuberculosis) during the covid-19 pandemic inpatient room at Labuang Baji Hospital Makassar showed a value $(0.005<0.05)$.

2. There is an influence between family support variables on treatment adherence of TB patients (tuberculosis) during the covid-19 pandemic, the inpatient room at Labuang Baji Hospital Makassar shows a value $(0.003<0.05)$.

3. There is an influence between anxiety on adherence to treatment for TB patients (tuberculosis) during the covid-19 pandemic, the inpatient room at Labuang Baji Hospital Makassar shows a value of $(0.001<0.05)$.

\section{REFERENCES}

[1] Anita Yeni, Erlisa Candrawati, Ragil Catur A.W. 2015 Pengetahuan Pasien Tubercullosis Brimplikasih Terhadap Kepatuhan Berobat. Universitas Tribhuwana Tungga dewi Malang.

[2] ArniWianti .2017,Hubungan Dukungan Keluarga Dengan Kepatuhan Minum Obat Pada Pasien Tuberculosis Paru. Di Puskesmas Kaladawa Kabupaten Tegal. 
[3] Eli Kurniasih, Vina Jovita Nurfajriani 2021. Gambaran Tingkat Kecemasan Pasien TB Paru Telaah Literatur. STIKes Bakti Tunas Husada Tasikmlaya.

[4] Kemenkes RI,2017. Data dan Informasi Kesehatan Profil Kesehatan Indonesia 2016

[5] Kementerian Kesehatan RI. (2020). Pedoman Pencegahan dan Pengendalian. Coronavirus Diseases (covid-19). Jakarta Selatan: KementerianKesehatan RI.

[6] Kementerian Kesehatan Republik Indonesia 2020, Pedoman Pencegahan dan Pengendalian COVID-19, accesed 18 mei 2020, available from UNIVERSITAS SUMATERAUTARA http://ww.kemkes.go.id/resorces/dowload/info-terkini/ COVID-19\%20corona virus\%20Disease\%20(COVID-19).pdf

[7] Infodatin TBC Indonesia. (2018). Tuberkolosis. Pusat Data danInformasiKementerianKesehatan

[8] Shen Et al. (2014). Pengaruh cognitive dan Acceptance and Commitment Therapy terhadap Ansietas, Depresi Klien Tuberkulosis. Jurnal Ilmiah Keperawatan. Vol 9. No 1 Surabaya

[9] WHO. (2020). Corona virus disease 2019 (COVID-19). URL http://www.euro.who.int/en/health-topics/healthmergencies/coronavirus-covid-19/technical-guidance/mental-health-and-covid-19 